\title{
PENARIKAN ARTIKEL \\ ANALISIS FUNDAMENTAL TERHADAP KINERJA KEUANGAN UNTUK PENGAMBILAN KEPUTUSAN PEMBELIAN SAHAM PADA PERUSAHAAN BUMN YANG TERDAFTAR DI BEI
}

\author{
Ellyn Octavianty, Muhamad Syahrial \\ Universitas Pakuan, Bogor
}

Penarikan Artikel

Berdasarkan hasil reviu yang cermat, hati-hati, dan penuh pertimbangan dari artikel yang berjudul ANALISIS FUNDAMENTAL TERHADAP KINERJA KEUANGAN UNTUK PENGAMBILAN KEPUTUSAN PEMBELIAN SAHAM PADA PERUSAHAAN BUMN YANG TERDAFTAR DI BEI Vol 6 (1), 16-25, 2014, makalah ini dinyatakan melanggar prinsip publikasi JIMFE (Jurnal IImiah Manajemen Fakultas Ekonomi) dan telah ditarik kembali.

Editor menyelidiki dan menemukan bahwa makalah yang diterbitkan di JIAFE (Jurnal Ilmiah Akuntansi Fakultas Ekonomi), Vol. 1 (1), hlm. 16-24, 2014.

Dokumen dan isinya telah dihapus dari JIMFE (Jurnal Ilmiah Manajemen Fakultas Ekonomi) dan upaya yang wajar harus dilakukan untuk menghapus semua referensi ke artikel ini.

\section{KETERANGAN ARTIKEL}

Arifulsyah, H. dkk. (2020). ANALISIS FUNDAMENTAL TERHADAP KINERJA KEUANGAN UNTUK PENGAMBILAN KEPUTUSAN PEMBELIAN SAHAM PADA PERUSAHAAN BUMN YANG TERDAFTAR DI BEI Vol 6 (1), 16-25, 2014. JIMFE (Jurnal Ilmiah Manajemen Fakultas Ekonomi), 6(1), 16-25. https://doi.org/10.34203/jimfe.v6i1.468

Copyright@2014. JIMFE (Jurnal IImiah Manajemen Fakultas Ekonomi) Universitas Pakuan 